Gut, 1963, 4, 13

\title{
A case of jaundice due to unilateral hepatic duct obstruction with relief after hepatic lobectomy
}

\author{
STEVEN MISTILIS AND LEON SCHIFF \\ From the Department of Medicine, University of Cincinnati College of Medicine, \\ and the Gastric Laboratory, Cincinnati General Hospital, Cincinnati, Ohio
}

EDITORIAL SYNOPSIS A case is reported of jaundice developing in a patient with obstruction of the left hepatic duct and partial obstruction of the right hepatic duct by tumour. Adequate drainage of bile from the right hepatic duct through a T-tube was relatively ineffective in relieving the jaundice. On the other hand, resection of the obstructed left lobe resulted in the disappearance of icterus. The basic mechanism involved in the production of jaundice under these circumstances is incompletely understood.

\section{CASE REPORT}

The patient (J.M.), a white man of 54 years, felt well until three weeks before admission to the Cincinnati General Hospital on 2 January 1962 when he noticed dark urine, pale stools, and yellowness of the whites of his eyes. Itching developed a week later and together with the jaundice, steadily increased up to the time of his admission. His appetite appeared unaffected and there was no weight loss. He said that he had experienced no abdominal pain, backache, nausea, vomiting, or gastrointestinal bleeding since the onset of his illness.

Physical examination showed marked icterus of the skin and sclerae. There were none of the peripheral signs of liver disease. There were numerous scratch marks on the skin. The heart and lungs were clear and there was no lymphadenopathy. The liver extended $9 \mathrm{~cm}$. below the right costal margin; its surface was smooth and not tender and no friction rub could be heard over it. The gall bladder and spleen were not palpable. No abnormal masses were felt. There were no signs of ascites. There was no peripheral oedema.

Routine laboratory tests contributed nothing. On admission the total serum bilirubin level was $22.6 \mathrm{mg} . \%$, the prompt reacting $12.0 \mathrm{mg}$. \%. The serum alkaline phosphatase was 8.4 Bodansky units per $100 \mathrm{ml}$. The cephalin

TABLE I

RESULTS OF LIVER FUNCTION STUDIES ${ }^{1}$

\begin{tabular}{|c|c|c|c|c|}
\hline Day of Admission & $\begin{array}{l}\text { Thymol Turbidity } \\
\text { (units) }\end{array}$ & $\begin{array}{l}\text { Cephalin Flocculation } \\
\text { (in } 24 \mathrm{hr} \text {.) }\end{array}$ & $\begin{array}{l}\text { Serum Bilirubin Prompt/ } \\
\text { Total ( } \mathrm{mg} . / 100 \mathrm{ml} \text { ) }\end{array}$ & $\begin{array}{l}\text { Serum Alkaline } \\
\text { Phosphatase } \\
\text { (Bodansky units } / 100 \mathrm{ml} \text {.) }\end{array}$ \\
\hline $\begin{array}{l}1 \\
6\end{array}$ & 3 & Negative & $\begin{array}{l}12 \cdot 0 / 22 \cdot 6 \\
21 \cdot 0 / 34 \cdot 0\end{array}$ & $8 \cdot 4$ \\
\hline 13 & 2 & Negative & $18 \cdot 4 / 32 \cdot 8$ & 8.4 \\
\hline 20 & 2 & Negative & $16 \cdot 0 / 26 \cdot 5$ & $7 \cdot 4$ \\
\hline 27 & & & $8 \cdot 3 / 16 \cdot 4$ & \\
\hline 31 & & & $5 \cdot 8 / 12 \cdot 6$ & \\
\hline 35 & 2 & Negative & $5 \cdot 2 / 11 \cdot 5$ & $9 \cdot 6$ \\
\hline 42 & & & $4 \cdot 7 / 9 \cdot 0$ & \\
\hline 48 & & & $11 \cdot 6 / 19 \cdot 4$ & \\
\hline 53 & 7 & Negative & $8 \cdot 2 / 14 \cdot 4$ & 8.5 \\
\hline 58 & & & $4 \cdot 5 / 7 \cdot 7$ & $8 \cdot 0$ \\
\hline 63 & & & $3 \cdot 0 / 6 \cdot 1$ & \\
\hline 70 & & & $2 \cdot 7 / 5 \cdot 3$ & \\
\hline 79 & 2 & $1+$ & $1.5 / 2.9$ & $10 \cdot 0$ \\
\hline 89 & 4 & $1+$ & $1.25 / 2.6$ & 11.7 \\
\hline 92 & 3 & $1+$ & $1.2 / 1.9$ & 12.4 \\
\hline 103 & 4 & $2+$ & $1.0 / 1.9$ & $13 \cdot 6$ \\
\hline 110 & 6 & Negative & $0.85 / 1.7$ & 14.0 \\
\hline 118 & 5 & $2+$ & $0.8 / 1 \cdot 7$ & 13.5 \\
\hline 125 & 6 & Negative & $0.6 / 1 \cdot 2$ & 14.3 \\
\hline
\end{tabular}

${ }^{1}$ Ten additional determinations repeated at less than weekly intervals have been omitted in order to shorten the table. 


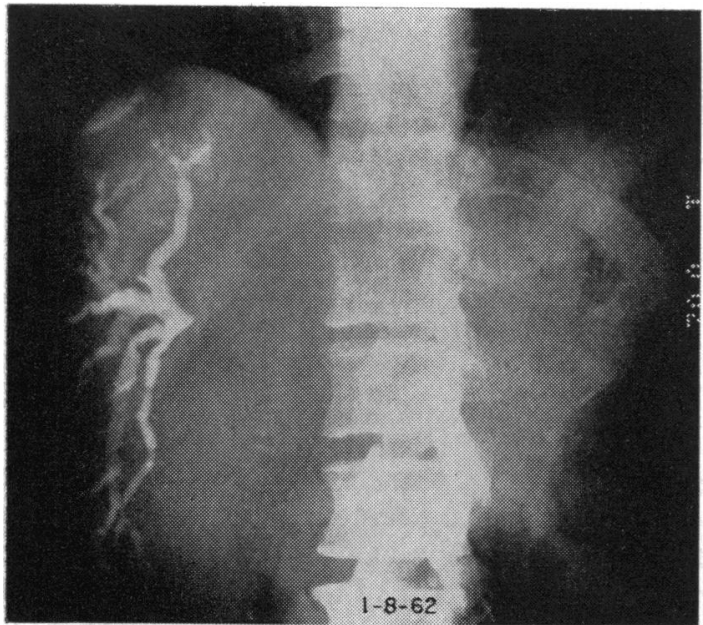

FIG. 1

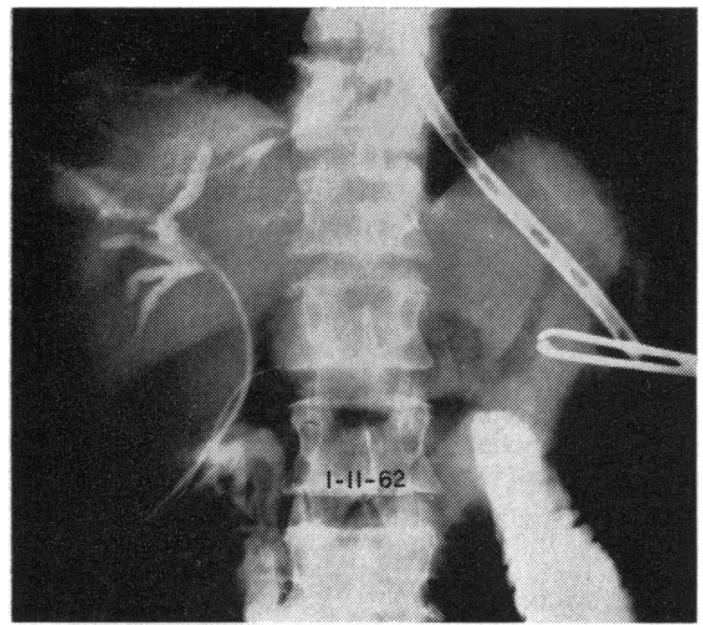

FIG. 2

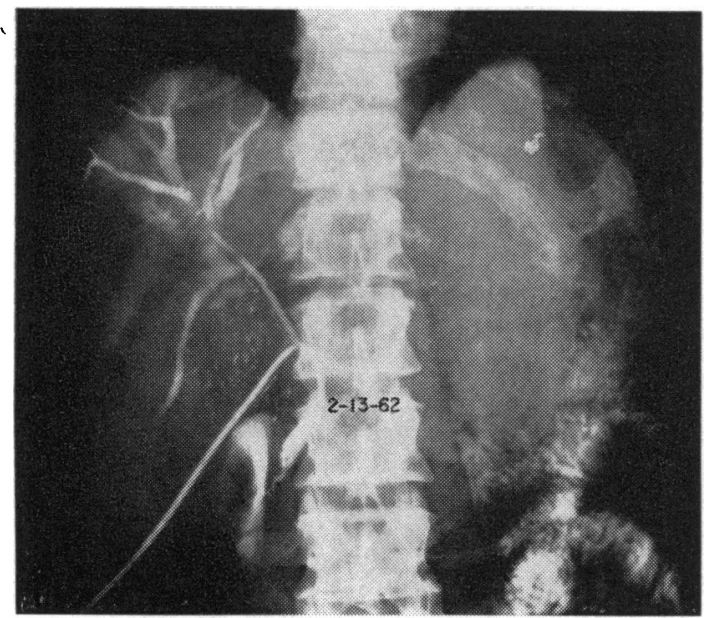

FIG. 3

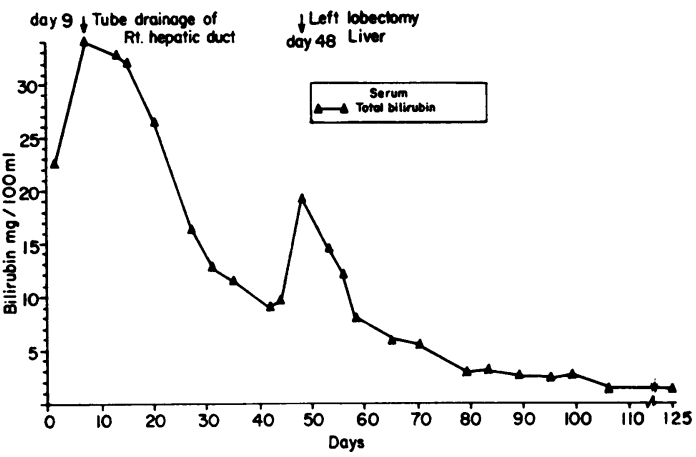

IIG. 4. The effect of T-tube drainage of right lobe and subsequent resection of left lobe of liver on the serum bilirubin.

cholesterol flocculation test was negative, the thymol and zinc sulphate turbidity, the total lipids, the serum proteins, and the prothrombin time were within normal range. The results of subsequent liver function studies are listed in Table $\mathrm{I}$.

A transthoracic biopsy of the liver was performed with a Vim-Silverman needle on the second day of admission and revealed changes characteristic of extrahepatic obstructive jaundice. Bile stasis was marked and there was infiltration with neutrophils and mononuclear cells about the portal triads.

A percutaneous transhepatic cholangiogram was done on the sixth day after admission. White bile was aspirated from the right lobe before the injection of $15 \mathrm{ml}$. of $70 \%$ urokon sodium solution and films made following introduction of the dye revealed distension of the bile ducts in this lobe with no filling of the ducts in the opposite lobe (Fig. 1). At operation on the ninth day a carcinoma was resected and curetted from the right main duct, but could not be removed from the left hepatic duct. An operative cholangiogram revealed dilatation of the ducts in the right lobe with no visualization of the left duct (Fig. 2). Drainage of bile could only be accomplished from the right lobe of the liver and this by means of a T-tube inserted into the right hepatic duct beyond the site of the tumour. The total serum bilirubin level dropped from a peak of $34 \mathrm{mg}$. $\%$ to $9.6 \mathrm{mg}$. \%, but began to rise again after six weeks to a level of $19.4 \mathrm{mg}$. $\%$. At this time a second laparotomy was done and an operative cholangiogram revealed the right hepatic duct to be patent but the left main duct was still completely obstructed (Fig. 3). Left hepatic lobectomy was performed by Dr. William A. Altemeier and section of the resected lobe showed complete occlusion of the left hepatic duct with no evidence of hepatic metastases. After this operation, the total serum bilirubin eventually fell to normal (Fig. 4). The pruritus disappeared as the icterus subsided. 


\section{CONCLUSIONS}

Experience in this case confirms previous reports of the occurrence of jaundice in patients with unilateral hepatic duct obstruction (Cattell and Braasch, 1960; Braasch and Preble, 1962). While regurgitation of bile from the obstructed lobe is the factor apparently responsible for the development of jaundice, the persistence of icterus in spite of adequate bile drainage from the unobstructed lobe and its disappearance following surgical removal of the affected lobe raises the question of whether the human liver is able to excrete conjugated bilirubin delivered to it. Arias, Johnson, and Wolfson (1961) have shown that the rat liver can excrete injected conjugated bilirubin but, to our knowledge, no such observations have been made in man. The difficulty in preparing a conjugated bilirubin (bilirubin glucuronide) suitable for use in man and the instability of such a product forestall its employment at present.

\section{REFERENCES}

Arias, I. M., Johnson, L., and Wolfson, S. (1961). Biliary excretion of injected conjugated and unconjugated bilirubin by normal and Gunn rats. Amer. J. Physiol., 200, 1091-1094.

Braasch, J. W., and Preble, H. E. (1962) Unilateral hepatic duct obstruction. Presented at the meeting of the American Gastroenterological Association, April 28, New York. Gastroenterology, 42, 743 (Abstract.)

Cattell, R. B., and Braasch, J. W. (1960). Repair of benign strictures of the bile duct involving both or single hepatic ducts. Surg. Gynec. Obstet., 110, 55-60. 